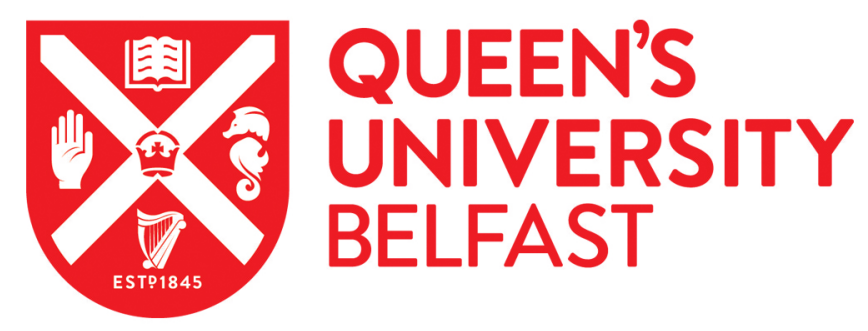

\title{
An evaluation of a Technology Enhanced Learning tool (Labtutor) from the perspective of undergraduate student nurses
}

McMullan, J. (2017). An evaluation of a Technology Enhanced Learning tool (Labtutor) from the perspective of undergraduate student nurses. International Journal of Innovative Research in Medical Science, 2(1), [24558737]. http://ijirms.in/index.php/ijirms-issue/current-issue/224-an-evaluation-of-a-technology-enhancedlearning-tool-labtutor-from-the-perspective-of-undergraduate-student-nurses

Published in:

International Journal of Innovative Research in Medical Science

Document Version:

Publisher's PDF, also known as Version of record

Queen's University Belfast - Research Portal:

Link to publication record in Queen's University Belfast Research Portal

Publisher rights

Copyright 2017 The Author. This is an open access article published under a Creative Commons Attribution License

(https://creativecommons.org/licenses/by/3.0/), which permits unrestricted use, distribution and reproduction in any medium, provided the author and source are cited.

\section{General rights}

Copyright for the publications made accessible via the Queen's University Belfast Research Portal is retained by the author(s) and / or other copyright owners and it is a condition of accessing these publications that users recognise and abide by the legal requirements associated with these rights.

Take down policy

The Research Portal is Queen's institutional repository that provides access to Queen's research output. Every effort has been made to ensure that content in the Research Portal does not infringe any person's rights, or applicable UK laws. If you discover content in the Research Portal that you believe breaches copyright or violates any law, please contact openaccess@qub.ac.uk. 


\title{
An Evaluation of a Technology Enhanced Learning Tool (Labtutor) From the Perspective of Undergraduate Student Nurses
}

\author{
Johanna McMullan \\ Medical Biology Center Queens University, Belfast, BT9 7BL United Kingdom
}

\begin{abstract}
:
The efficiency of large group teaching (lectures) has long been called into question with much research high lighting low levels of student participation, and poor attention spans leading to a lack of engagement with learning which inhibits deep learning. Small group teaching and Enquiry Based Learning (EBL) are methods of teaching that can help promote deep learning. There is also a growing need and demand for Technology Enhanced Learning to suit changing lifestyles. The Labtutor ${ }^{\circledR}$ System, is one such piece of software that is designed to incorporate EBL and small group teaching quality into the large group setting.
\end{abstract}

This study provides a descriptive survey of adult nursing student's perceptions of the Labtutor system following its use in two Life Science modules within an undergraduate nursing programme. A convenience sample of first year adult nursing students ( $n=$ 115) were identified to complete a 32 item questionnaire (appendix three).

Participants reported overall that they enjoyed using the system and found it beneficial to their learning specifically:

(a) Increased engagement with material in online learning as a result of using the system.

(b) Increased participation and levels of interactivity in the lecture as a result of using the system.

(c) Increased enhancement of learning as a result of using the system and

(d) Usefulness of the formative assessment facilitated by using the system.

The study concludes that Labtutor ${ }^{\circledR}$ system and other such methods of Technology Enhanced Learning packages if used correctly can enhance learning.

Keywords: Technology Enhanced Learning.

\section{Introduction}

Many teachers believe that life sciences cannot be taught using interactive techniques, while some believe that undergraduate students, due to their more limited basic knowledge, cannot participate in an interactive lecture (Haigh, 2004). However, there is also current opinion that conventional lectures should be replaced by 'structured interactive sessions' (Steinery and Snell, 1999; Race, 2006). Moreover, interactive techniques allow teachers to receive feedback on students' needs, on how information has been assimilated, and on future learning directions, while students receive feedback on their own knowledge or performance (Laurillard, 2002). Interactive lecturing is a way to benefit from the strengths of small group learning in large group format (Kumar, 2003; Bain, 2004). Although 'active learning' was not defined precisely in educational literature, some general characteristics are commonly associated with the use of strategies promoting active learning in the classroom. It was previously suggested that 'active learning' involves students in doing things and in thinking about what they are doing (Keyser, 2000). In order to get the students involved, many learning/ teaching models and techniques may be used, including experiential learning, cooperative learning, problem-solving exercises, writing tasks, speaking activities, class discussions, case-study methods, simulations, role-playing, peer teaching, fieldwork, independent study, library assignments, computer-aided instruction and homework (Keyser, 2000; Legan, 2001; McLaughlin and Mandin, 2001; Micheal, 2001; Haigh 2004 and Johnson et al 2010).

Among many teaching models that have been suggested to make the lectures more interactive, is the expository model. The expository model encourages meaningful learning. The teachers present material in a carefully organized, sequenced and finished form. In this model, one of the major components in constructing the lecture is to provide the students a framework or a 'big picture' of the lecture to enable the students to receive the most usable material in the 


\section{International Journal of Innovative Research in Medical Science (IJIRMS) Volume 02 Issue 01 January 2017, ISSN No. - 2455-8737 \\ Available online at - $\underline{w w w . j i j i r m s . i n}$}

most efficient way, organizing knowledge into hierarchical and integrated patterns, from the general to the specific and completing the lecture by the reinforcement of the cognitive schema (Chung and Huang, 1998; Ivie, 1998; Zarotiadou and Tsaparlis, 2000). Aspects of technology enhanced learning is an example of an expository model.

Black and Watties -Daniels (2006) reviewed the literature relating to technology enhanced learning in teaching in general and found a large amount of literature supporting technology as an enhancement to the learning environment, but no literature specific to nurse or medical education. Simpson (2003) discussed how technology was transforming nurse education e.g. simulation patients, yet none were being used in the traditional lecture setting. Kennerly (2001) suggests using interaction in lecturing to facilitate student interaction. Walsh and Seldomridge (2006) encourages nurse tutors to move away from the model of delivering all the details in class to re-structuring content to allow students to discuss and be openly involved in the classroom to promote critical thinking e.g. problem solving tasks and case studies.

It is interesting to note that the literature also seems to suggest that while lectures are being poorly rated by most students, students of nursing and life science seem to like them especially in first year (Al-Modhefer and Roe, 2009). As a teaching strategy, the traditional lecture is one to which most students have adapted throughout the educational process to provide them with the necessary information for their classes (Race, 2006. Further, experience indicates that students have an increased comfort level with this traditional teaching methodology, partly because they can remain in a passive role as they are not expected to answer questions etc. Students report a preference for receiving didactic instruction that provides the information they believe they need to know. Many students indicate a decreased comfort level with non-traditional teaching methods such as use of case studies and EBL because of a need to be prepared, become an active participant, and change their role from passive to active learner (Delpier, 2006).

Al-Modhefer and Roe's (2010) study suggest that when nursing students come into university for the first time, they appear to favour lectures with a preference for clear and organised instruction. Although these results are from a single higher institution cannot be generalized, further evidence support's lectures as the favourable means for teaching and learning life sciences (Davies et al (2008) with $72 \%$ of students agreeing that lectures contributed to their learning and understanding of life science. A recent study found that students felt "overwhelmed" at the prospect of having to embark on on-line or self-directed learning, and wanted "old school" lectures to base learning on (Charbonneau 2012). Leamnson (1999) noted that first year students in particular want lectures and tutor contact to guide their learning and fear being "left alone". The same author writes of how all students and again in particular first year students report the importance of experience as part of their learning. "They need to experience concepts as their lone learning is not developed enough for connections to be made simply from reading" (Leamnson, 1999).

The literature clearly indicates the components of good teaching and how to ensure deep learning in students. That didactic teaching should not be so heavily used as modern students can access information quickly and easily and trying to deliver too much content in large group lectures is of little benefit. Although small group teaching has many good qualities it can also have drawbacks unless these session are well facilitated and are not nearly a repeat of the lecture. Furthermore, with constraints on time and resources lectures will remain a part of third level education and the literature seems to suggest that one mustn't throw out the baby with the bath water. Well-structured lectures that engage students and involve active learning are not only as good as other methods of teaching they can inspire students and it would seen are actually wanted by students especially in the first year when they can feel overwhelmed at the prospect of self-learning (Beder 1997). It should also be noted that not all students are computer literate; therefore if lecturers are to facilitate learning including distance learning it must be directed. It would seem then that a "good " lecture should introduce the main themes and concepts, involve the students and then direct them on how to continue to learn in a structured and inspired way at their own pace. There must also be adequate feedback built into the module so students do not feel "adrift" when continuing to learn alone. Technology Enhanced Learning (TEL) is the term used to describe all those circumstances where technology plays a significant role in making learning more effective, efficient or enjoyable (Goodyear and Retalis, 2010). Many different types of technology can be used to support and enhance learning. "Technology" in its broadest sense includes hardware; such as interactive whiteboards, smart tables, handheld technologies, tangible objects, and software for example computer-supported collaborative learning systems, learning management systems, simulation modelling tools, online repositories of learning content and scientific data, educational games, web 2.0 social applications, 3D virtual reality, etc. Technology continues to change dramatically, with the majority of university students now owning a mobile phone or other hand held device which gives them access to the internet (Castells 2006). One such TEL programme available is Labtutor ${ }^{\circledR}$ Labtutor ${ }^{\circledR}$ is a computer based teaching programme which combines the use of software and hardware to aid in the teaching of human physiology principles. It is an HTML-based software package, designed specifically for laboratory teaching and 


\section{International Journal of Innovative Research in Medical Science (IJIRMS) Volume 02 Issue 01 January 2017, ISSN No. - 2455-8737 \\ Available online at - $\underline{w w w . j i j i r m s . i n}$}

used in conjunction with AD Instruments PowerLab®. There are several experiments which demonstrate physiological changes such as respiration rate, changes in blood pressure etc. Students can conduct these very "safe" experiments on each other using an extensive range of hardware equipment such as exercise bike, PEAK flow meter etc. The student's results are stored on their own "site" and questions are asked of them to interpret the results guiding them through learning. The software allows the Lecturer to pick and choose from the various experiments and insert one's own resources and questions to make a tailor made resource for the student's learning outcomes. The program is augmented with case studies, background reading and video clips to enhance learning. The lecturer can pick and choose whether to include or not. For the purposes of this study the Labtutor® system was used in the lecture setting and experiments conducted on live subjects to demonstrate some aspects of physiology such as the effect of exercise on blood pressure and respiration rate. Tutorials were then uploaded for the students to do at their own pace and the students used the results which they had seen being conducted to attempt to answer questions related to the experiments. The tutorials were "online" for students to access wherever and whenever they could or wanted. There were checkpoints to ensure students were progressing satisfactorily. Tutorials were structured so that one could not progress unless each section was successfully completed, thus giving the student a degree of formative assessment as they progressed.

The literature also reminds us that modern students are "technology friendly". Bain (2013) suggests that students can read and access information faster than lectures can talk, and often their information is more up to date than year after year repeated lectures. Race (2012) stipulates that students have at their fingertips all the knowledge that the tutor has, however Kantanis (2002) reminds us that often students access information via poor "google" searches and do not process the skills of critically evaluating resources. A survey of some 3000 students revealed that students are demanding more technological resources such as videos, gaming, quizzes and learning management systems so they can control their own learning and complete work at their own pace (Undergraduate Technology Survey 2012). It must be remembered however, that not all students are "tech-savvy" especially mature students (Kevern and Webb, 2004) and that nursing in particular has a larger number of mature students compared to other disciples. So it is imperative that any use of technology and/ or learning management systems must be used with guidance and caution.

\section{Purpose of the study}

The aim of this study is to investigate if students find the Labtutor ${ }^{\circledR}$ beneficial to their learning.

\section{Objectives}

(a) To ascertain level of student engagement with material in online learning as a result of using the system.

(b) To gauge participation and levels of interactivity in the lecture as a result of using the system.

(c) To determine enhancement of learning as a result of using the system.

(d) To determine the usefulness of formative assessment facilitated by using the system.

This study provides a descriptive survey of adult nursing student's perceptions of the Labtutor system following its use in two Life Science modules within an undergraduate nursing programme. A convenience sample of first year adult nursing students $(n=115)$ were identified to complete a 32 item questionnaire comprising of a number of multiple choice questions using Likert Scales. The results of this questionnaire were analysed and are presented using a mixture of tables and graph.

The questionnaire was constructed using a five point Likert scale (ranging from "strongly agree" to "strongly disagree" and an "undecided" option, and a few yes /no answer questions. The questions were generated from specific themes and gaps in knowledge identified from the literature. In order to facilitate such a large group, to ensure confidentiality, ease of collation of data and to keep the time needed to complete to a minimum the Personal Response System (PRS) was used to facilitate the data collection.

The PRS provides each student with a credit card sized handset with several buttons on it, which transmits radio signals to a receiver in the lecturer's computer according to which button is pressed. The receiver tabulates the responses and can present them on screen in various formats (e.g. as a pie chart, graph or bar chart) in less than a second from the last response, or when the lecturer clicks the mouse for all to see.

Students were invited to respond to a series of questions posed regarding the use of Labtutor ${ }^{\circledR}$ by pressing their PRS handset. Each response had a corresponding button on the handset. The system enables the facilitator to see when all participants had responded. Participants could change their responses at any time up to the point when the next question was posed, however if required they could also request at a later point to change a response, or have a response or all responses from them deleted, however no participant availed of this option. 


\section{Validity and Reliability}

The questionnaire was reviewed and examined by several experienced teachers including fellow Life Science Lecturers, Information Technology experts and an Education Technologist who had all been briefed on the study.

A pilot study was conducted on a small group of 14 students from a different cohort who had also used the system. As a result of the pilot study and suggestions from experts several small changes were made to the questionnaire including the number of negative questions, the time allowed for some questions, the number of questions allotted to each concept and the wording of some questions.

\section{Sampling}

The researcher conducted all the lectures and wrote the material for the tutorials and the group of 115 students for whom the researcher had teaching responsibility were also the convenient sample group for the study.

Ethical application was made to the School Research Ethics Committee, and granted. Students were informed at the start of the module by way of verbal instruction that they would be using the Labtutor ${ }^{\circledR}$ system and extensive instruction on how to do so was given. It was emphasised on both occasions that participation was entirely voluntarily and there would be no repercussions if they chose not to, nor personal benefit gained if they did. Consent therefore was gained by attendance.

\section{Data Analysis}

A major benefit of using the system to collect the data from the questionnaire is its ability to collate the data via its "creating reports" function. Data is analysed using statistical tests similar to SPSS programme calculating confidence intervals and statistical inference. Question responses can be compared against each other, a breakdown of male/female respondents and responses' by age can also be compared. This results in a plethora of statistical outcomes available which must be carefully considered. Descriptive statistics such as frequencies were therefore used to represent the data. Student responses are presented using a mix of pie charts and graphs that represent both numbers responding and percentage of the study population. Quantitative data is presented using the initial aims of the study to provide clarity.

The data was analysed using the statistical package incorporated into the P.R.S system, and the results are presented under the study objectives.
Of 115 possible participants who met the inclusion criteria, 92\% $(\mathrm{n}=106)$ chose to complete the questionnaire a response rate of $92 \%, 91 \%(\mathrm{n}=97)$ were female and $9 \%(\mathrm{n}=10)$ were male. These figures are in keeping with the predominantly female gender of nurses and are supported by the Nursing and Midwifery Council (NMC) (2008) who state that $89 \%$ of registered nurses are female. The spread of ages was also representative of those nursing students in general, and provided useful information on the difference of opinion according to age. The $18-25$ categories made up $75 \%$ of the group $(\mathrm{n}=80), 26-35$ groups were $17 \%(\mathrm{n}=18)$ the remainder $8 \%(\mathrm{n}=8)$ in the $36-45$ categories.

\section{Key findings}

The findings from this study clearly indicate that students found the use of Labtutor ${ }^{\circledR}$ in their undergraduate course to be a positive experience with $92 \%$ ( $\mathrm{n}=97$ ) finding its use enjoyable and $84 \%(\mathrm{n}=87)$ finding it beneficial to their learning. When asked if they would like the system used in future lectures $77 \% \quad(\mathrm{n}=81)$ reported they would. Furthermore $76 \%(\mathrm{n}=79)$ said they would recommend the use of the system to other nursing students.

\section{Engagement with material in online learning as a result of using the system.}

Engagement happens along a continuum and is a matter of degrees of involvement (Avendano, 2003). Though the student has the responsibility to engage in academic activities, it is the lecturer's role to create purposeful course designs that promote interaction, participation, and communication in the online learning environment (Weiss et al., 2000; Johnson, 2003). Educators and instructors have to consciously and consistently develop and sustain different opportunities that will encourage engagement in online education. HEI's are in a position to support technological innovations that promote the development of skills (Conrad and Donaldson, 2004). Participants in this study believed that online material was more interesting $(71 \% \mathrm{n}=74)$ when it was based on experiments they had seen facilitated by using the Labtutor ${ }^{\circledR}$ system, so it would seem that the system helped students to engage with learning.

Furthermore, student engagement pertains to the time and physical energy that students expend on activities in their academic experience (Jacobi et al., 1987; Kuh, 2003). Engagement also relates to the efforts of the student to study a subject, practice, obtain feedback, analyse, and solve problems (Kuh, 2003). Participants $(75 \% \mathrm{n}=80)$ felt more motivated to complete online work using the system as it allowed further development of concepts and experiments introduced in lectures. It would seem them that the Labtutor ${ }^{\circledR}$ system has the capacity to enable lecturers to design learning materials that motivate and engage students 


\section{International Journal of Innovative Research in Medical Science (IJIRMS) Volume 02 Issue 01 January 2017, ISSN No. - 2455-8737 \\ Available online at - $\underline{w w w . j i j i r m s . i n}$}

with regards to online learning and assist students to embrace the technology that already exists to support online learning.

There is no change in higher education more sweeping than the transformation brought about by the advent of the Internet and Web (Robinson et al., 2008). Maeroff (2003) maintained that developments in online learning are not "just a fad" but a "sea change" (p. 2). The amalgamation of knowledge and technology permits higher education to provide learning opportunities anytime, anyplace, and to anyone (Aggarwal and Bento, 2000; Maeroff 2003; Pittinsky, 2003). In this study $80 \%(n=84)$ of participants reported that they would find it helpful if they could access the system remotely supporting the concept that modern students are comfortable with and even desire remote study.

The Internet and related technologies make possible creative and cutting-edge pedagogy such as online learning modules, that permits innovation for the teaching-learning process (Lowy and Ticoll, 1998; Burgstahler, 2000) and have been used effectively to enhance such learning (Cole, 2000). The elimination of time and place constraints, and the availability of flexible and innovative channels for interaction online have increased the opportunities for learning (Chickering and Ehrmann, 1996; Burgstahler, 2000).

Responses to the questions relating to engagement with online material when the Labtutor ${ }^{\circledR}$ system was used were overwhelmingly positive. Respondents felt they could relate to online material better when it was based on experiments they had seen in lectures $(78 \% \mathrm{n}=82)$ suggesting that Labtutor ${ }^{\circledR}$ helps achieve better engagement.

However, while the prevalent concept of an online environment allows content to be delivered in many ways and eases the task of interaction (Palloff and Pratt, 2001), there must still be a degree of lecturer/ student interaction and the material ought to be a continuation of that introduced by the teacher (Benbunan-Fich et al., (2005). Tackling new concepts online on their own is not recommended (Bucy, 2003: Conrad and Donaldson, 2004). The design of materials should focus on increasing student interaction with materials to increase motivation (Johnson, 2003).

Student engagement pertains to the time and physical energy that students expend on activities in their academic experience (Jacobi et al., 1987; Kuh, 2003). Engagement pertains to the efforts of the student to study a subject, practice, obtain feedback, analyse, and solve problems (Kuh, 2003). Participants in this study felt more motivated to complete online work using the system $(75 \% \mathrm{n}=80)$ as it was a continuum from concepts and experiments introduced in lectures and students were therefore more engaged with their online learning. It would seem them that the Labtutor ${ }^{\circledR}$ system can help lecturers design online materials that motivate and engage students with regards to online learning.

\section{Enhancement of learning as a result of using the system.}

Often lectures are crammed with key information with little time for full exploration whereas the Labtutor ${ }^{\circledR}$ system aims to foster a "deep" approach to learning by introducing key concepts in lectures by way of demonstration of live experiments and then directing students to relate this information to further study online. The overall aim of "deep" learning as opposed to surface or rote learning is so that students retain and truly understand the key concepts (Snelgrove 2004). The majority of participants in this study agreed $(79 \% \mathrm{n}=84)$, that the system both helped them to conceptualize key concepts, which according to Kuh (2003) is the first step in deep learning. Participants also reported understanding concepts when the system was used $(88 \%$ $\mathrm{n}=92$ ) further demonstrating a deep as opposed to surface approach (Lorenzo and Moore, 2002). Most importantly, participants $(63 \% \mathrm{n}=64)$ found it easier to retain their learning when Labtutor ${ }^{\circledR}$ had been used to teach the information.

Linnenbrink and Pintrich (2003) reminds us that if a student believes that a teaching tool is helping them to learn their positive attitude towards the tool will help students to engage in and take responsibility for their learning, therefore promoting "deep" learning as opposed to panicked "rote" learning. It is of great significance then that when asked if Labtutor ${ }^{\circledR}$ was not beneficial to them in terms of learning, the strongest response was yielded with $88 \% \quad(n=91)$ disagreeing and when asked if overall the use of the system was beneficial to their learning $84 \%(n=90)$ responded yes. Clearly the participants in this study valued Labtutor as a learning tool.

\section{Participation and levels of interactivity in the lecture as a result of using the system.}

Bligh (1998) suggests that in the long term large group teaching is not effective in terms of student learning, as students are passive recipients of information, without engagement in the learning process, and therefore their attention wanes quickly after 15-25 minutes. (Conoley et al., 2006), recommending introducing a learning activity or change in teaching technique, even just a small break every 20 minutes to significantly increase the learner's attention. The results of this study appear to support this as $81 \%$ $(n=84)$ felt they were more attentive in lectures when the 


\section{International Journal of Innovative Research in Medical Science (IJIRMS) Volume 02 Issue 01 January 2017, ISSN No. - 2455-8737 \\ Available online at - $\underline{w w w . j i j i r m s . i n}$}

system was used as it introduced interest and a break from the norm of didactic teaching.

Furthermore traditional didactic lectures can potentially facilitate passive learning, without any active engagement by the students (Gulpinar and Yegen, 2005). Where learners are passive in the learning process they demonstrate limited attention spans and low retention rates of factual information from lectures (Fischer et al., 2004; Gulpinar and Yegen, 2005)

However as a teaching strategy, the traditional lecture is one to which most students are exposed to throughout the educational process to provide them with the necessary information for their classes (Race, 2006). Students have an increased comfort level with this traditional teaching methodology, partly because they can remain in a passive role as they are not expected to answer questions etc. Literature supports interactive teaching methodologies as promoting increased understanding and application of knowledge as well as retention of factual knowledge (Costa et al., 2007). A carefully structured lecture can be an effective way to combine and present information from multiple sources on complex topics (Richardson, 2008).

The literature also supports the use of lecture as an effective teaching methodology for clarification of difficult concepts, organisation of thinking, and promotion of problem solving (Naismith and Steinert, 2001). In this study 66\% (n=69) of participants felt more involved in lectures when the system was used in lectures and suggests that if the lecturer can successfully reframe the delivery from being strictly oneway communication and engage learners, then it can be a successful tool in the learning process (Di Leonardi, 2007).

Relevant literature does not support the belief that lectures should be completely abolished and the current opinion is that conventional lectures should be replaced by 'structured interactive sessions' (Steinert and Snell, 1999; Race, 2006).

Black and Watties-Daniels (2006) reviewed the literature relating to technology and enhanced learning in teaching in general and found a large amount of literature supporting technology as an enhancement to the learning environment. Participants in this study $76 \%(n=80)$ found the lectures more interesting when the system was used, supporting these concepts and challenging how lectures should be delivered. Studies have indicated that students are more likely to attend lectures if they contain interaction over didactic teaching alone (Traphagan 2005; Martyn 2009). Only $49 \%(n=51)$ of participants in this study agreed that they would be more likely to attend lectures if the Labtutor ${ }^{\circledR}$ system was used, which although was still positive was one of the lowest positive response rate. However, when asked if they would be less likely to attend $83 \%(n=86)$ disagreed implying that the system certainly did not put them off attending. It is worth noting that $21 \%$ of participants' were undecided when asked if they would be more likely to attend, perhaps this could be interpreted as the students believing they would attend lectures irrespective if they didn't enjoy them or find them beneficial. Nevertheless the results indicate that they would not be less likely to attend if a tool such as Labtutor was to be used.

Al-Modhefer and Roe's (2010) study suggests that when nursing students come into university for the first time they appear to favour lectures with a preference for clear and organised instruction. Furthermore, Davies et al (2000) found in their study that $72 \%$ of students agreed that lectures contributed to their learning and understanding of life science. A recent study found that students felt "overwhelmed" at the prospect of having to embark on online or self-directed learning, and wanted "old school" lectures to base learning on (Charbonneau 2012). Leamnson (1999) noted that first year students in particular want lectures and tutor contact to guide their learning and fear being "left alone". The same author writes of how all students and again in particular first year students report the importance of the experience of attending lectures and being part of a group as part of their learning.

It was of interest then to establish if participants would like to use the system in future lectures, in other life science module and if they would recommend its use to other nursing students. Responses yet again were positive; with $76 \%(n=79)$ recommending its use to other nursing students. A significantly high proportion would like to use the system in other life science modules $(81 \% \mathrm{n}=84)$ and $77 \%(\mathrm{n}=81)$ agreeing they would like it used in future lectures. Labtutor is a physiology and life science based module. Question 27 asked if participants would like to use this type of interactive learning in other modules that were not life science based which only yielded a positive response of $63 \% \quad(n=65)$ significantly lower than the other questions relating to this theme. However it is difficult to ascertain if this question confused the participants as in retrospect it could have been clearer that it related to this type of interactive learning rather than solely Labtutor.

\section{Usefulness of the formative assessment facilitated by using the system.}

The Labtutor® system provides prompt feedback to students as it identifies where they are achieving and where not, individually and immediately. First years in particular desire feedback (Wilcox et al., 2005) and it has been argued that it is essential for their development as they are not skilled at identifying gaps in their knowledge (Rhodes and Nevill, 2004: Yorke and Longden, 2007). The participants in this study $(88 \% \mathrm{n}=89)$, certainly seem to agree that it helped to 


\section{International Journal of Innovative Research in Medical Science (IJIRMS) Volume 02 Issue 01 January 2017, ISSN No. - 2455-8737 \\ Available online at - $\underline{w w w . j i j i r m s . i n}$}

identify what they understood, and that it helped to identify gaps in their knowledge $(72 \% \mathrm{n}=75)$. However participants were less sure if it helped them identify their learning needs $(57 \% \mathrm{n}=59)$ or if they would use this information to direct further study with only $50 \%(n=50)$ agreeing or strongly disagreeing with this statement. However, what is significant about the responses to these statements was that $30 \%(n=32)$ were undecided in both, which suggests that the participants did not feel strongly that they would not use the information to direct their study and could be interpreted that perhaps that they didn't know how to and this concurs with the literature that suggest that students especially first years struggle to utilise feedback to direct their learning (Beder, 1997: Yorke and Longden 2007). It is also interesting to note that this question produced a significant difference in responses through the age range whereby $50 \%$ of 18-25 year olds agreed or strongly agreed in contrast to $71 \%$ of the $36-45$ group. Again this supports literature that suggests that mature students are better at applying feedback to direct further study than younger students (Richardson, 2006: Young, 2010). However, it must also be remembered that mature students can also struggle with online course work (Barakzai and Fraser, 2005) Perhaps there is a need to further explain to students especially in first year how to direct further study once furnished with this feedback, as this can be difficult especially with online material (Schwartz and White, 2000).

\section{Online material and self-directed learning}

The modern student both wants and demands interactive learning (Undergraduate Technology Survey, 2012), and have a wealth of knowledge and information at their fingertips (Race 2012). However, it is important to recognise that not all students are "Tech-savvy", especially mature students (Jones 2012) and that first year students in particular can feel abandoned if they are "set adrift" in the world of self-directed learning (Leamnson, 1999). It was noted by the researcher during the teaching of the module that some students had reported gaining access to the material online as being difficult when using the system; therefore this question was included in the questionnaire. Interestingly $17 \% \quad(\mathrm{n}=17)$ agreed/strongly agreed, $20 \%$ $(n=21) \quad$ were undecided, however $63 \% \quad(n=65)$ disagreed/strongly disagreed. It is difficult to ascertain if this is because the Labtutor ${ }^{\circledR}$ system in particular was difficult to get access to, or because the students were very new to the course as they were only in their first phase, but it is imperative that lecturers must ensure when embarking on teaching using such a system that it is accessible and that help and support is available for those having difficulties or some students may be "left behind" or unduly stressed.

The participants were however overwhelmingly positive to the question regarding working remotely, as $80 \%(\mathrm{n}=84)$ agreed/strongly agreed and $11 \%(n=12)$ were undecided with only $9 \%(n=9)$ disagreeing/strongly disagreeing when asked if they would like the capability to access the system 24/7 from phones, laptops etc. This may be a reflection on the fact that students now more than ever have demanding lifestyles requiring them to work as well as study, and increasing numbers have families (Gillet et al., 1997). If having remote access enabled students to achieve more study at convenient times, saving travelling etc. then this would be positive, however it must be pointed out that again as discussed earlier students especially first year need and want feedback. Therefore a limit must be set especially initially on the amount of remote learning set as it is important that students come together, and have regular contact with lecturing staff. Furthermore it is important that sound group dynamics are formed early on, as is crucial for the success of a problem based curriculum (Albanese and Mitchell 1993)

Lastly, the system also provides the capability for students to conduct the experiments on their own or in small groups rather than just observing them. In response to the question "I believe my learning would be further enhanced if I had the chance to conduct the experiments myself", $73 \%(n=78)$ agreed/ strongly agreed, $14 \%(\mathrm{n}=15)$ undecided and $14 \%$ $(n=14)$ disagreeing/strongly disagreeing. Self-participation would seem to be desired by the majority of participants however, facilitating this would be a huge commitment in terms of resources for rooms, equipment and staff and would need to be justified. Morison et al (2004) contend that teamwork and collaboration are increasingly regarded as important goals in healthcare, and working through experiments in small groups could help facilitate this. Furthermore, actually "doing" experiments may suit some students learning styles especially "pragmatists" and "activists" (Honey and Mumford 1986) therefore promoting “deep" learning.

\section{Conclusions}

The ultimate aim of nurse education is to produce practitioners fit for practice in possession of professional knowledge. Findings from this study raise a number of challenges for nurse educators not least how to deliver the new curriculum in such a way as to promote deep learning and understanding, and engage students enabling them to link theory to practice to meet the NMC progression points (NMC, 2010). To simply deliver information to large groups of students didactically fails to encourage engagement with learning and therefore it could be argued does not promote deep learning. Ideally small group sessions involving interactive activities such as with Labtutor ${ }^{\circledR}$ and teaching strategies such as enquiry based learning can achieve deep learning. However, with continuing demands on resources it is unlikely that whole programmes can be delivered in this 


\section{International Journal of Innovative Research in Medical Science (IJIRMS) Volume 02 Issue 01 January 2017, ISSN No. - 2455-8737 \\ Available online at - $\underline{w w w . j i j i r m s . i n}$}

way, and large group teaching seems likely to continue for the foreseeable future.

Recent advances in educational technology can go some way to assist the lecturer in implementing new teaching strategies. Furthermore, changing lifestyles and more demanding schedules are forcing more students to reap the benefits of academic instruction remotely (Glen 2006). The demand for distance education is growing exponentially and has been for some time. However the increasing need for online resources as a learning strategy must be used with caution. It must be of good quality and have adequate instruction on how and when to complete tasks and how to access help when necessary. Educators must acknowledge these facts and strive to incorporate the positive aspects of small group teaching such as interaction making lectures as interesting as possible to engage students and promote learning. Labtutor ${ }^{\circledR}$ as a Technology Enhanced Learning Tool was used in this study to help achieve this.

The participants in this study were overwhelmingly positive regarding the use of the Labtutor® program as part of their Life Science Module. Participants agreed that lectures were more interesting when the system was used, that they were more attentive in lectures and that they would be more likely to attend if the system was used. Participants also felt more involved in lectures when the system was used, and that they would like it used not only in other life science modules but in other subjects. Furthermore participants overwhelming agreed that they would recommend the systems use to other students.

With regards to feedback, the participants in this study also reported the system to be useful in identifying the gaps in their knowledge and that they would use this information to direct further study. Participants believed the system helped them conceptualise more easily and helped them retain information better. It is perhaps then unsurprising that they also reported that it was therefore beneficial to their learning as it assisted in fostering deep as opposed to surface learning. Therefore it provides the lecturer with a tool to help engage students more in lectures and promote learning. It would be interesting to further investigate if the students retained more information due to this increased involvement. Participants also believed that if they were able to conduct the experiments themselves that this would further enhance their learning and it would be interesting to carry out a follow up study to investigate if there was a detectable difference in outcomes between groups if one had conducted experiments and the other group simply observed them.

The participants in this study were very new to tertiary level education and as discussed previously it is imperative that educators' do not overwhelm new students with problem based remote learning as they can feel adrift. This study clearly demonstrates that a system such as Labtutor ${ }^{\circledR}$ can help link the information presented in lectures to online learning and structure online material so students can work at their own pace but still feel supported. Participants in this study also reported that they would welcome the capability to be able to work entirely remotely on tablets etc. which reinforces other research describing the modern students need and desire for remote learning.

\section{Limitations}

Although the results of this study are overwhelmingly positive it must be remembered that this was a single centred study based in one Higher Education Institution in the United Kingdom. The results also need to be taken cautiously as they examine in some instances perceived effect e.g. enhancement of learning, improved retention of information etc., it is difficult to see if they actually have positive effects. Further study would be needed to confirm these effects. Educators are intending to embark on using such an online system such as Labtutor ${ }^{\circledR}$ should be aware that the initial outlay is expensive and there are strict licensing implications. This may pose some difficulties especially for smaller institutions. As discussed earlier some student's especially mature students may not be "tec-savy" and need careful instruction on how to access and use the system or they could be "left behind".

Lastly caution must be exercised when using the prewritten experiments, case studies and the other multiple resources available. They should be used to augment teaching and not used to replace it. Furthermore, the resources must be adapted to match the curriculum and should not be used as an "off the shelf", bought curriculum as it is not designed to do so.

\section{Main Recommendations}

A number of recommendations arise from this study:

- HEIs should consider investing in Technology such as Labtutor® to enhance large group teaching and the quality of small group teaching into the large group setting and Technology such as the Labtutor ${ }^{\circledR}$ can certainly help achieve this. The material presented in lectures must be linked clearly to tutorials and online learning for it to be worthwhile and again systems like Labtutor ${ }^{\circledR}$ clearly help to achieve this.

- Educators must also strive to assist students to work remotely and at their own pace, but must ensure that students particularly those new to this level of education are carefully guided as to what to study and how to assess the material and feel 


\section{International Journal of Innovative Research in Medical Science (IJIRMS) Volume 02 Issue 01 January 2017, ISSN No. - 2455-8737 \\ Available online at - $\underline{w w w . j i j i r m s . i n}$}

supported. Again systems such as Labtutor® seem to help facilitate this and give structure to a module.

- $\quad$ The Personal Response System should be utilised more as it provides the student with the opportunity to participate more fully, particularly in large lectures and provides the lecturer with feedback.

- This initiative could be supported by for example the development of an "App" to further promote interest and indeed support for remote learning.

\section{References:}

1. Aggarwal, A. K., and Bento, R. (2000) Web-based education. In A. Aggarwal (Ed.), Web-based learning and teaching technologies: Opportunities and challenges (pp. 2-16). Hershey, PA: Idea Group.

2. Al-Modhefer, A.K. and Roe, S. (2009) Nursing Students' attitude to biomedical sciences lectures. Nursing Standard 24 (14) 42-48.

3. Avendano, J. (2003) Student involvement: Assessing student satisfaction, gains, and quality of effort (No. AAT 3115177). Bloomington: Illinois State University. (Proquest Digital Dissertations

4. Bain, K. (2004) What the best college teachers do. Cambridge, Mass. Harvard University Press.

5. Bain, K. (2013) What's wrong and right with lectures. Best Teachers Summer Institute. June, 1921

6. Barakzai, M. D., and Fraser, D. (2005) The effect of demographic variables on achievement in and satisfaction with online coursework. Journal of Nursing Education, 44(8), 373-380.

7. Beder (1997) "Addressing the Issues of Social and Academic Integration for First Year Students." ultiBASE.

8. Benbunan-Fich, R., Hiltz, S., and Harasim, L. (2005) The online interaction learning model: An integrated theoretical framework for learning networks. In S. Hiltz \& R. Goldman (Eds.), Learning together online: Research on asynchronous learning networks (pp. 19-38). Mahwah, NJ: Erlbaum.

9. Black, C. D. and Watties-Daniels, A. D. (2006) Cutting edge technology to enhance nursing classroom instruction. ABNF Journal, pgs 103-106

10. Bligh, D. (1998) What's the use of lectures? (5th Edition) Intellect, Exeter.

11. Bucy, M. C. (2003) Online classes: The student experience (No. AAT 3098412). Corvallis: Oregon State University. (Proquest Digital Dissertations)
12. Burgstahler, S. (2000) Web-based instruction and people with disabilities. In F. Cole (Ed.), Issues in web-based pedagogy: A critical primer (pp. 389396). Westport, CT: Greenwood Press.

13. Castells, M. (2006) Mobile communication and society: A global perspective. Cambridge, MA: MIT Press.

14. Charbonneau, L. (2008) Students prefer good lectures over the latest technology in class. University Affaires. Novemeber Vol (21)

15. Chickering, A. W. and Ehrmann, S. C. (1996) Implementing the seven principles of good practice in undergraduate education: Technology as lever. Accounting Education News, 49, 9-10.

16. Cole, F. (2000) Issues in web-based pedagogy: A critical primer. Westport, CT: Greenwood Press.

17. Conoley, J., Moore,G.,Croom,B. and Flowers, J. (2006) A toy or teaching tool? The use of an audience-based response systems in the classroom. Techniques, 81(7), 46-48

18. Conrad, R. and Donaldson, J. A. (2004) Engaging the online learner: Activities and resources for creative instruction. San Francisco: Jossey-Bass

19. Chung, J.M, and Huang, S.C. (1998) The effects of three aural advance organizers for video viewing in a foreign language classroom, System, 26, pp. 553 565.

20. Conrad, R. and Donaldson, J. A. (2004) Engaging the online learner: Activities and resources for creative instruction. San Francisco: Jossey-Bass

21. Costa ML; van Rensburg L. and Rushton N; ( 2007) Does teaching style matter? A randomised trial of group discussion versus lectures in orthopaedic undergraduate teaching. Medical Education, 2007 Feb; 41 (2): 214-7.

22. Davies, R. (2008) The Bologna process: The quiet revolution in nursing higher education. Nurse Education Today. 28, pp 935-942.

23. Delpier T; (2006) Cases 101: learning to teach with cases. Nursing Education Perspectives, 2006 JulAug; 27 (4): 204-9

24. Di Leonardi, B.C. (2007) Tips for facilitating learning: The lecture deserves some respect. The Journal of Continuing Education in Nursing, 38, 154-161.

25. Fisher, R.; Jacobs, S. and Herbert, W. (2004) Small-group discussion versus lecture format for third year students. Obstetrics Gynaecological Vol (104) 349-353

26. Gillet, D., Salzmann, C., Longchamp, R. and Bovin, D. (1997) Telepresence: An opportunity to develop real-world experimentation in education. European Contr. Brussels. 


\section{International Journal of Innovative Research in Medical Science (IJIRMS) Volume 02 Issue 01 January 2017, ISSN No. - 2455-8737 \\ Available online at - $\underline{w w w . j i j i r m s . i n}$}

27. Goodyear, P. and Retalis, S. (2010) TechnologyEnhanced Learning: Design Patterns and Pattern Language. Sence Publishers Rotterdam.

28. Glen, S. and Cox, H. (2006) E-Learning in nursing: the context. In: Glen, S., Moule, P. (Eds), Elearning in Nursing. Palgrave MacMillan, Houndmills.

29. Gülpinar M; and Yegen BÇ. (2005) Medical Teacher, Nov; 27 (7): 590-4.

30. Haigh,J. (2004) Information technology in health professional education: why I.T matters. Nurse Education Today. Vol: 24, 547-552

31. Honey, P. and Mumford, A. (1982) The Manual of Learning Styles, Peter Honey, Maidenhead.

32. Ivie, S.D. (1998) Ausubel's learning theory: an approach to teaching higher order thinking skills, High School Journal, 82, pp. 35-42

33. Jacobi, M., Astin, A. and Ayala, F., Jr. (1987) College student outcomes assessment. Washington, DC: Clearinghouse on Higher Education.

34. Johnson, J. (2003) Distance education: The complete guide to design, delivery, and improvement. New York: Columbia University Press.

35. Johnson, N., List-Ivankovic, W.O., Eboh, J., Ireland, D., Adams, E. and Martindale, J. (2010) Research and evidence based practice: Using a blended approach to teaching and learning in undergraduate nurse education. Nurse Education in Practice. Vol:10, 43-47

36. Kantanis, T. (2002). Same or different: Issues that affect mature age undergraduate students' transition to university. Paper presented at the $6^{\text {th }}$ Pacific Rim First-Year in Higher Education Conference, Christchurch, New Zealand.

37. Kennerly, S. (2001) Fostering interaction through multimedia. Nurse Educator. 26 (2), pgs 90-94

38. Kevern, J. and Webb, C. (2004) Mature women's experiences of preregistration nurse education. Journal of Advanced Nursing, 45(3), 297-306.

39. Keyser, M.W. (2000) Active learning and cooperative learning: understanding the difference and using both styles effectively, Research Strategies, 17, pp. 35-44.

40. Kuh, G. (2001) Assessing what really matters to student learning. Change, 33, 10-17.

41. Kuh, G. D. (2003) What we're learning about student engagement from NSSE. Change, 35, 2431.

42. Kumar, S. (2003) An innovative method to enhance interaction during lecture sessions. Advances in Physiology Education, 27, pp. 20-25.
43. Leamnson, A. (1999) Developing habits of learning with first year college and university students. St.Tylus Publishing.

44. Laurillard, D. (2002) Rethinking University Teaching: A framework for the effective use of learning technologies'. Routledge/ Falmer, London.

45. Legan, S.J. (2001) Multiple-format sessions for teaching endocrine physiology, Advances in Physiology Education, 25, pp. 228-232.

46. Linnenbrink, E. A. and Pintrich, P. R. (2003) The role of self-efficacy beliefs in student engagement and learning in the classroom. Reading and Writing Quarterly, 19, 119-137.

47. Lorenzo, G. and Moore, J. (2002) The Sloan Consortium report to the nation: Five pillars of quality online education. Needham, MA: Sloan Consortium, Inc. Retrieved October 30, 2004, from http://www.sloan-c.org/effectivepractices

48. Lowy, A. and Ticoll, D. (1998) Blueprint to the digital economy: Creating wealth in the era of ebusiness. New York: McGraw-Hill.

49. Maeroff, G. I. (2003) A classroom of one: How online learning is changing our schools and colleges. New York: Palgrave MacMillan.

50. Martyn, M.A (2009) Engaging Lecture Capture: Lights, Camera... Interaction! http://facweb.cdm.depaul.edu/mmartyn/elc.pdf

51. McLaughlin, K. and Mandin, H.A. (2001) Schematics approach to diagnosing and resolving lecturalgia, Medical Education, 35, pp. 1135-1142.

52. Naismith, L. and Steinert, Y. (2001) The evaluation of a workshop to promote interactive learning. Teaching and Learning in Medicine, 13, 43-48.

53. Nursing and Midwifery Council (2008) Standards to Support Learning and Assessment in Practice. London. NMC.

54. Nursing and Midwifery Council (2010) Standards for pre-registration nursing education. London. NMC. Available at http:/standards.nmcuk.org/Pages/Welcome.aspx.

55. Palloff, R. M. and Pratt, K. (2001) Lessons from cyberspace classroom. San Francisco: Jossey- Bass.

56. Pittinsky, M. S. (2003) The wired tower: Perspectiveson the impact of the internet on higher education. Upper Saddle River, NJ: Pearson Education

57. Race, P. (2006) In at the deep end- starting to teach in higher education. Leeds Metropolitan University.

58. Race, P (2011) Learning for the Future, in Blue Skies: new thinking about the future of higher education, London: Pearson 
59. Rhodes, C. and Nevill, A. (2004) "Academic and Social Integration in Higher Education: a survey of satisfaction and dissatisfaction within a first-year education studies cohort at a new university." Journal of Further \& Higher Education 28(2): 179193.

60. Richardson, D. (2008) Don't dump the diactic lecture, fix it. Advanced Physiology Education. Vol (32) 23-24

61. Robinson,C. and Hullinger, H. (2008) New Benchmarks in Higher Education: Student Engagement in Online Learning.Journal of Education for Business 101-113

62. Rhodes, C. and Nevill, A. (2004) "Academic and Social Integration in Higher Education: a survey of satisfaction and dissatisfaction within a first-year education studies cohort at a new university." Journal of Further \& Higher Education 28(2): 179193.

63. Schwartz, F. and White, K. (2000) Making sense of it all: Giving and getting online course feedback. In K. White \& B. Weight (Eds.), The online teaching guide: A handbook of attitudes, strategies, and techniques for the virtual classroom (pp. 167-182). Needham Heights, MA: Allyn \& Bacon.

64. Simpson, R.L. (2003) Welcome to the virtual classroom: How technology is transforming nursing education. Nursing Administration Quarterly, 27 (1) pgs 83-86

65. Snelgrove, S.R. (2004) Approaches to Learning of student nurses. Nurse Education Today. Vol (24) 605-614

66. Steinery, Y. and Snell, L.S. (1999) Interactive lecturing: strategies for increasing participation in large group presentations, Medical Teacher, 21, pp. 37-42.

67. Traphagan, T.; Kyoko, J. and Kishi, K. (2010) Impact of class lecture webcasting on attendance and learning. Educational Technology Research and Development February 2010, Volume 58, Issue 1, pp 19-37

68. Undergraduate Technology Survey (2012) Educational Centre for Applied Research. www.educause.edu > Library

69. Walsh, CM. and Seldomridge, L.A. (2006) Critical thinking: Back to square two. Journal of Nursing Education. 45 (6) pgs. 212-219.

70. Wilcox, P., Winn, S. and Fyvie-Gauld, M. (2005) "'It was nothing to do with the university, it was just the people': the role of social support in the first-year experience of higher education." Studies in Higher Education 30(6): 707-722.
71. Weiss, R. E., Knowlton, D. S. and Speck, B. W. (2000) Principles of effective teaching in the online classroom. San Francisco: Jossey-Bass.

72. Young, J.M.; Kristoffersen, D.T.; O'Brien, M.A. and Oxman, A.D. (2010) Audit and feedback: effects on professional practice and health care outcomes (Review) 1. The Cochrane Collaboration. Published by John Wiley \& Sons, Ltd

73. Zarotiadou, E. and Tsaparlis, G. (2000) Teaching lower-secondary chemistry with a Piagetian constructivist and an Ausubelian meaningfulreceptive method: A longitudinal comparison. Chemistry Education: Research and Practice in Europe, 1, 37-50. 